\title{
Setting-Up Characteristics Needs of Customer E-Commerce Business Dieter
}

\author{
Muhammad Danang Prasetyo $^{1}$, Andina Oktariani $^{1 *}$, Arif Imam Suroso ${ }^{1}$ \\ ${ }^{1}$ School of Business IPB University \\ ${ }^{*}$ Corresponding author. Andina.oktariani@apps.ipb.ac.id
}

\begin{abstract}
Public awareness of the importance of health and a healthy lifestyle is increasing. Diet wants and needs are the healthy lifestyle that most people choose. In practice, there are still many people who do not know the principles of a healthy diet and still have an inappropriate diet. This study aims to identify and analyze community problems in dieting. The method used in this study uses an empathy map, which is part of the design thinking method. The results of this study found that 62 percent of consumers were worried about their diet not producing the results they wanted to achieve in their diet, 74 percent of consumers said that in dieting, they experimented with diets that were known to be effective and 80 percent of consumers found it difficult to be consistent in their diet. control the diet that is done for several reasons such as often tempted to go back to eating unhealthy foods, often lack the motivation to continue the diet, no visible results when doing a diet. This research is expected to be used as a reference for compiling the right solutions for the e-commerce dieter business.
\end{abstract}

Keywords - dietary, problem, empathy map

\section{INTRODUCTION}

The Indonesian people are now starting to realize the importance of health for life, namely by adopting a healthy lifestyle. This is evidenced by research conducted by Unilever in 2016 [1] that percent of consumers in Indonesia have started to choose healthy foods and are aware of the importance of health. This number is predicted to increase to 24 percent in 2020, which is predicted by more and more people who are active in leading a healthy lifestyle. This is what encourages the development of Indonesian people to adopt an increasing diet. According to the latest survey conducted by Nielsen's New Global and IngredientSentiment in 2016, 80 percent of respondents said they had a diet that restricted or prohibited the consumption of unhealthy food/drinks and 64 percent of respondents said they were willing to pay more for unhealthy food/drink. contains unhealthy ingredients. According to San RK et.al [2], the Indonesian people already know a lot about and follow a diet, especially to lose weight. The purpose of this community diet is to improve appearance, maintain ideal body weight, and prevent the risk of disease due to excess body weight. However, many people are wrong about the true principles of the diet. According to Firi RP's research [3], 44 out of 71 respondents or 62 percent said that they still felt doing it unhealthy in their diet. They rely more on doing a diet in a strict way, such as eating less drastically by following a diet based on the experience of people who are successful on a diet, to buying and using drugs for diets to get results quickly or "instant", all of which have not been proven to match. with other people's body conditions, it is safe medically and when the diet is not right with the body's condition it can harm health. For this reason, this study aims to identify and analyze the characteristics and problems of consumers who want to go on a diet so that it can be used as a reference for developing various solutions to implement the correct and appropriate diet lifestyle.

\section{MATERIALS AND METHODS}

This research was conducted using an empathy map, one of the stages of the design thinking method. Empathize is a stage to help researchers understand what consumers see, feel, and experience. 
Empathization is done to identify problems experienced by consumers. According to d.school [4], empathy can be done using the engaging method, namely interacting and interviewing the target consumer group. Interviews are conducted to be able to understand a person's thoughts, emotions, and motivations in making choices and habits so that they can identify their needs. In this study, empathy was carried out using in-depth interviews. In-depth interviews are used to be able to explore in more depth the perspectives, experiences, feelings, and perspectives of respondents on dieting. The research was carried out in Jakarta, Bogor, Depok, Tangerang, and Bekasi.

At the research stage, the number of consumers taken was 35 respondents who had been on a diet. The data used in this study consisted of primary data and secondary data. Primary data were obtained by conducting in-depth interviews and also distributing questionnaires to respondents. Meanwhile, secondary data is obtained through literature studies from various sources such as publications, journals, the internet, and previous theses. In this study, the data analyzed were qualitative. The data analysis techniques used were categorization and reduction techniques. The categorization technique is the process of rearranging notes from observations or interviews into a more systematic form [5]. While reduction techniques are activities to summarize, choose main things, focus on important things, and look for themes and patterns [6].

\section{RESULTS AND DISCUSSION}

The empathizing stage is carried out to understand what consumers see, feel, and experience in a diet. The details of the empathy map in this study are as follows.

\subsection{What respondents think and feel (think and feel)}

This section provides an overview of how they feel and think about their experiences on a diet. Based on the empathize results obtained, some of the things that the respondents thought and felt were: (1) 21 respondents said the reason they were on a diet was that they felt that their body had become heavy and fat so that the respondent wanted to go on a diet to improve their appearance as well as reasons to prevent the risk of disease due to being overweight. (2) 21 respondents also went on a diet because they didn't feel confident about their body shape. (3) 19 respondents were worried that the diet being carried out was wrong or not following their body condition. (4) 22 respondents were also worried about the diet that they did not produce the results they wanted to achieve in their diet. (5) 26 respondents answered that their diet has a goal of improving their appearance because they feel insecure about their body shape and weight. (6) 14 respondents answered that their diet had the aim of preventing the risk of disease that could strike at any time if they did not do a diet.

\subsection{What respondents said and did (say and do)}

This section provides an overview of what respondents said and did when doing a diet. The results of this section are: (1) There is 77 percent who say they are looking for diet information by looking at online media such as (apps, YouTube, social media). (2) There is 74 percent said that in dieting, they experimented with diets that are known to be effective. (3) There is 71 percent said that in experimenting with a diet program, they follow the experiences of people who have successfully used the diet program, and (4) there is 68 percent in doing a diet that they are often hungry their eyes or want to eat unhealthy foods so it's hard to be consistent.

\subsection{What are the problems/difficulties of the respondent (pain)}

This section is the part where respondents describe the problems or obstacles they feel when they go on a diet. The results of this section are: (1) Respondents find it difficult to consistently control their diet for several reasons, such as being tempted to go back to eating unhealthy foods, often lack the motivation to continue the diet, no results are seen when to go on a diet. This problem is the problem most experienced by respondents as many as 28 out of 35 respondents, namely 80 percent. (2) When they want to go on a diet, respondents find it difficult to get correct diet information, and according to their body condition. Respondents said they experimented with the types of diets that were available to find a diet that suited them and this would have a negative impact if the dietary information carried out was wrong and not following the respondent's body condition. This problem was experienced by respondents as many as 25 out of 35 respondents, namely 71 percent. (3) When doing a diet, respondents find it difficult to know the nutrients contained in the food ingredients they want to consume so they only look in general or just follow the information available in online media and it does not necessarily match their body's needs. This problem was experienced by respondents as many as 19 out of 35 respondents, namely 54 percent. (4) Respondents find it difficult to find foodstuffs to make their diet food because it is difficult to find the desired ingredients and also do not have time to buy foodstuffs in markets or supermarkets. These problems have an impact on their consistency in dieting. This problem was experienced by respondents as many as 17 out of 35 respondents, namely several 48 percent. (5) 
Respondents when doing a diet feel inconsistent in dieting because they are too busy with their activities such as studying or working so that they do not have free time to cook their diet food. This problem was experienced by 12 of 35 respondents, namely 34 percent. (6) Respondents when doing a diet find it difficult to find the desired and easy food recipe to make them and also respondents feel they do not know how to process food ingredients properly because the way of processing food ingredients can also affect the nutritional content contained in the diet food consumed. This problem was experienced by 10 out of 35 respondents, which was 28 percent.

\subsection{What respondents see (see)}

This section is a section that contains an overview of what respondents saw or paid attention to regarding dieting. Based on the results of problem identification, several things that the respondents saw or paid attention to were: (1) 77 percent said that they saw a lot of current diet information on online media such as applications, YouTube, social media. (2) There is 57 percent said that from the amount of information there is still a lot of dietary information that is incorrect or inconsistent and also not proven by the research. (3) There is 48 percent who go on a diet see diet suggestions from doctors or influencers on online media. (4) There is 71 percent of those who go on a diet by looking at the experiences of people who are successful on a diet and good reviews from people who see it too.

\subsection{What respondents hear (hear)}

This fifth section describes what the respondent hears that can give influence and information that can influence it. Based on the results of problem identification, several things that were heard by the respondent were: (1) There was 51 percent who heard that the diet had to reduce the portion of food. (2) There is 65 percent who hear diet advice from friends and relatives. (3) There was 62 percent who heard that every meal provided had to be varied. (4) There is 77 percent who heard that a wrong diet will harm the body. (5) There are 57 percent heard that food ingredients for the diet are more expensive than usual food ingredients.

\subsection{What do respondents want (gain)}

The last section contains what the respondents want to do on a diet. The majority of respondents want the following: (1) There is 71 percent want to get diet information from nutritionists so that the diet is suitable for their body condition. (2) 80 percent want to be able to control their diet easily. (3) There are 45 percent said that they want to have an influential diet and make their diet healthy. (4) 51 percent said they wanted to be able to find dietary needs easily. (5) 51 percent also want to get information on the nutritional content of the food ingredients they want to consume on a diet easily.

The characteristics and behavior of respondents in doing this diet are summarized in the empathy map which can be seen in Figure 1. Based on the empathy map, it can be seen that the reason consumers go on a diet is due to improving their appearance and also to prevent the risk of disease. Then in doing a diet, consumers often experiment with diet programs that are seen or heard from online media, then follow the experiences of people who have succeeded in doing diets which are still not necessarily following the body condition of each consumer so consumers need diet information correct and following the condition of their bodies. Furthermore, in doing a diet, consumers have a problem, namely, it is difficult to be consistent in controlling their diet because there are still many consumers who find it difficult to refrain from eating unhealthy foods and cannot wait to get the desired results so they use all means to quickly get the results of the diet. desired. Besides, consumers are not consistent in dieting is a busy activity or work that makes it difficult for consumers to diet consistently. The next problem is that consumers still do not understand the information about the nutritional content in food and also find it difficult to find the needs for making diet foods.

\section{CONCLUSION AND RECOMMENDATION}

The results of this study found that 62 percent of consumers were concerned about their diet not producing the results they wanted to achieve in their diet, 74 percent of consumers said that in dieting, they experimented with diets that were known to be effective and 80 percent of consumers found it difficult to be consistent in their diet. control the diet that is done for several reasons such as often tempted to go back to eating unhealthy foods, often lack the motivation to continue the diet, there are no visible results when doing a diet. Besides, it is difficult to get the right diet information according to the body's condition as much as 71 percent and do not understand the nutritional content of the food ingredients used as much as 51 percent. The results of research on mapping the problems of consumers who are on a diet provide direction that there need to be supporters to facilitate the community in dieting correctly, precisely, and easily. Various solutions to solve diet problems are important so that they do not have an impact on public health. 


\section{REFERENCES}

[1] Nainggolan SY.2018. Survei : Makanan Sehat Makin Disukai Masyarakat Indonesia.[Internet].[diunduh pada 2020 Februari 24]. Tersedia pada : https://www.medcom.id/rona/kesehatan/GK dQLDrN-survei-makanan-sehat-makindisukai-masyarakat-indonesia.

[2] San RK, Danoko C, Budiman A. 2018. Analisis Dan Perancangan Marketplace Katering Diet Berbasis Web. Jakarta (ID): Universitas Bina Nusantara.

[3] Firi RP. 2016.Pengaruh Teman Sebaya, Pengetahuan, Media Masa Terhadap Perilaku Diet Mahasiswi Stikes Payung Negeri Pekanbaru.Pekanbaru.Jurnal Endurance 3(1) Februari 2018 (162-168).

[4] [d.school] Institute of Design at Stanford. 2013. Bootcamp Bootleg. [Internet]. [diunduh 2020
Januari 21]. Tersedia pada: https://s3.xopic.de/openhpipublic/courses/1NcWQVnyTA0dLYw9kHLs4e/r tfiles/35m0Q8qXYjvHO7FHuwgVgg/bootcamp bootleg2010.pdf

[5] Kountur. 2009. Metode Penelitian untuk Penulisan Skripsi dan Tesis. Jakarta (ID): Sekolah Tinggi Manajemen PPM.

[6] Sugiyono. 2009. Metode Penelitian Kuantitatif, Kualitatif dan R\&D. Bandung (ID): Alfabeta.

\section{APPENDIX}

Figure 1 Empathy Map

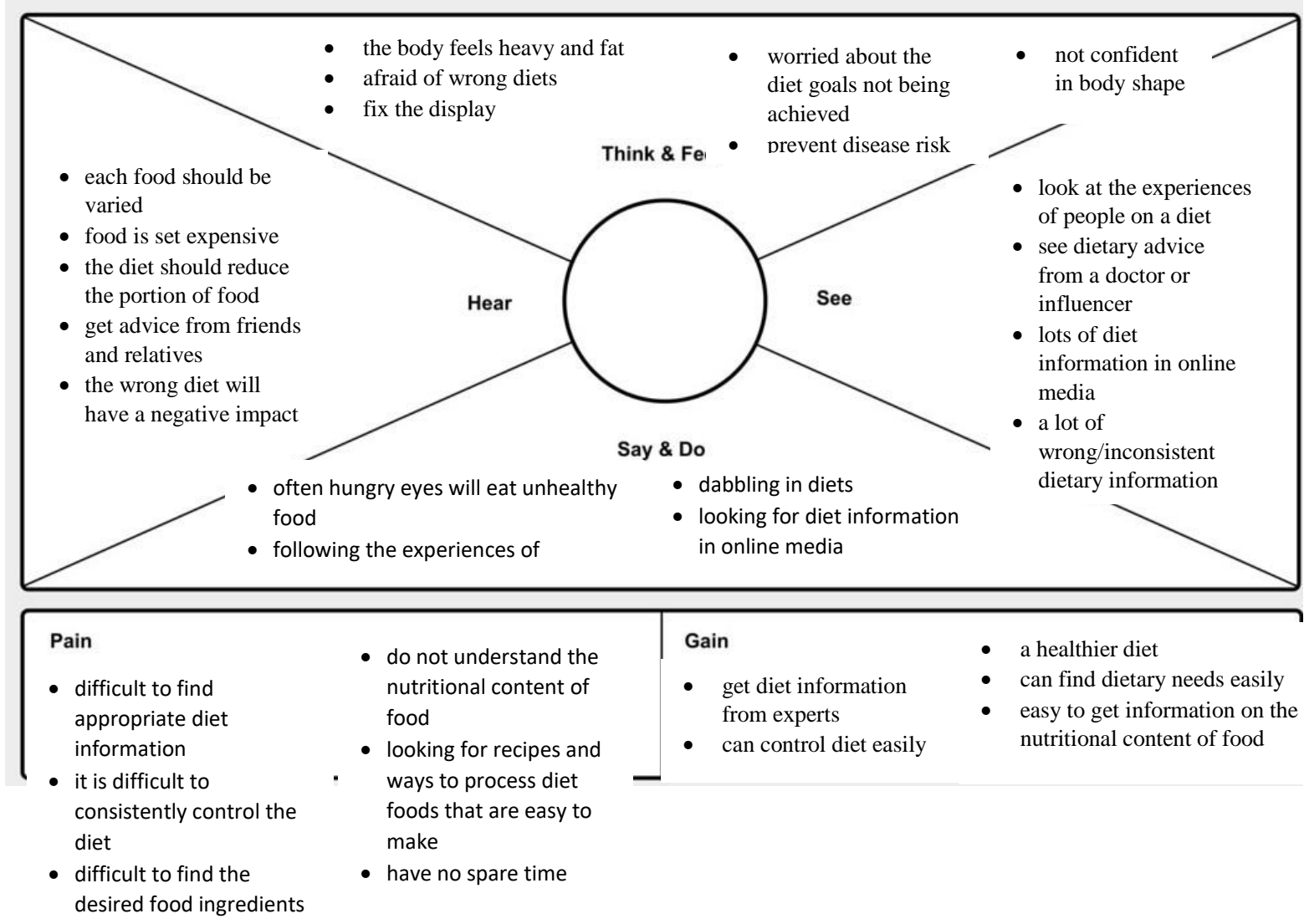

